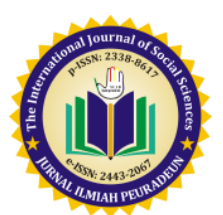

\title{
MODEL-BASED DEVELOPMENT OF ENGLISH LANGUAGE LEARNING CHARACTERS IN IMPROVING STUDENTS ACHIEVEMENT OF SMA
}

\author{
Sariakin \\ Serambi Mekkah University Banda Aceh \\ Email: sariakin70@gmail.com
}

Received: Aug 23, 2015

Accepted: Dec 07, 2015

Published: May 28, 2016

Article Url: https://journal.scadindependent.org/index.php/jipeuradeun/article/view/95

\begin{abstract}
The purpose of this study is to discover, describe and explain the development model of character-based English language in senior high schools to improve student's achievement. This study is designed to approach research and development, the research is followed up by studying, investigating, and understanding as well as how the model-based development of English Language learning character develop. The sample of the study consists of 30 teachers who are taken from 8 senior high schools in Banda Aceh that have the same background and characteristics. To produce a model of teaching English in senior high schools in Banda Aceh, the model is conducted systematic steps in the form of the process of action, reflection, evaluation, and innovation. The method used is direct observation, questionnaires, interviews, seminars, and development. Furthermore, this research is expected to produce English language-based learning model character in accordance with the national culture.
\end{abstract}

Keywords:Development, English Language-Based Characters 


\section{A. Introduction}

English subjects have different characteristics with exact subject or subjects of other social sciences. This difference lies in the function of language as a communication tool. This indicates that learning English is not only to learn vocabulary and grammar in the sense of knowledge, but should seek to use or apply that knowledge in communication activities. A student can not be said to be proficient in English if he was not able to use English for communication purposes, even though he gets good grades on vocabulary and grammar.

Language is a basic cultural forms produced by man and to humanize humans in every generation in a community language. In addition, the language is said to be the cultural basis for being the primary means of forming various forms and types of other cultures. Thus, differences in language into surface marker pattern of differences in system and culture. More can be said also that the differences in the systems and cultural patterns become markers of different characteristics, traits, or character of a community language. Briefly want to say that no two languages or two cultures together on this earth (Mackey, 1997: 132).

Stevick in Subana (2009: 28) express purpose of teaching is to improve selfesteem, promote positive thinking, increase self-understanding, cultivate intimacy with others, and being able to find strengths and weaknesses.

Therefore, a subject in English is directed to develop these skills so that graduates are able to communicate and discourse in English at a certain level of literacy. Literacy rate:

a. Literacy levels include performative, functional, informational, and epistemic.

b. In the performative level, people are able to read, write, listen, and talk to the symbols used.

c. At the functional level, people are able to use language to meet the needs of daily life such as reading a newspaper, manual or instruction.

d. At the informational level, people are able to access knowledge with the ability to speak

e. At the epistemic level of knowledge to be able to express in the target language (Wells, 1987: 76). 
Next, to meet the human resource, education has a very important role. This is in accordance with Law No. 20 Year 2003 on National Education System in Article 3, which states that the national education serves to develop the ability and shape the character and dignified civilization in order to educate the nation. National education aims at developing students' potentials in order to become a man of faith and fear of God Almighty, noble, healthy, knowledgeable, capable, creative, independent, and become citizens of a democratic and responsible. Meanwhile, one to get an education with noble values, moral, creative and have a corresponding character of national culture can be obtained through the use of good language. As highlighted in the above statement, the language appears to have a role in management and create the next generation of value-added. For that reason, the need to analyze further how the role of language in character education (Law of the Republic of Indonesia Number 20 of 2003).

In accordance with the statement mentioned above, the development of the intellectual, social and emotional education language (eg English) has a central role and is supporting the success in studying all fields of study. Language learning is expected to help learners recognize themselves, their culture, and the culture of others. In addition, language learning also helps learners are able to express ideas and feelings, participate in society, and even discover and analytical skills and imaginative that was in him.

This is related to the formation of the character of the students so that they can compete, ethical, moral, good manners and interact with the community. Based on research at Harvard University, United States (Ibrahim Ali Akbar, 2000), it turns out a person's success is not determined solely by the knowledge and technical abilities (hard skills), but rather by the ability to manage themselves and others (soft skills). Character is the values of human behavior associated with the Almighty God, ourselves, our fellow human beings, the environment, and nationality embodied in thoughts, attitudes, feelings, words, and actions based on religious norms, laws, manners, culture, and customs.

Character education is a system of cultivation of character values to the school community, which includes knowledge, awareness or willpower, and actions to implement these values, both to God Almighty (Almighty), 
ourselves, others, the environment, or nationality so that a man perfect man. Regardless of the various deficiencies in the practice of education in Indonesia, when seen from the national education standards as the reference curriculum development (SBC), and the implementation of learning and assessment in schools, educational goals can actually be achieved by either. Coaching character is also included in the material to be taught and mastered and realized by learners in everyday life. The problem, character education in schools during this new level touching on the introduction of norms or values, and yet at the level of internalization and concrete actions in everyday life.

English is one of the communications media in the form of oral and written. Can or is able to use English, the demands of life today because almost all electronic media are used daily are programmed using the English language; his example is Mobile Phone and Computer. English Lessons have four skill or skills are: Reading (Reading), Speaking (Speaking), Writing (Writing) and Listening (Listening). As an international language, English is used in communication in the fields of science, technology, trade, politics, and the areas in which many nations have an interest.

Given the importance of the position of English in Indonesia, then the need for institutions that can facilitate the teaching of English. One official government agencies participate in developing English language is a school. The school is one place/institution where English is taught, ranging from elementary school to high school and even up to the level of Higher Education. The school students are taught in English in the form of oral and in written form (written cycle). This is a challenge that needs to find a way out through a study, and the study will find English teaching model based characters that can improve the performance of students at the same school achievement.

\section{B. Method}

In accordance with the objectives to be achieved, this study was designed to approach research and development (Borg \& Gall, 1989: 254), which followed research by developing a program with the aim to improve or enhance the condition of the object under study. To produce a model of the development of character-based English language learning in high school performed systematic steps in the process of action, reflection, evaluation, 
and innovation. The method used in collecting the data is Observation, Questionnaire, Interview, Seminar and Development

\section{Research Finding and Discussion}

Stages of research are a process that must be passed researcher systematically. In terms of data collection researchers have gone through various phases as planned, in the form of collecting data through observation, distributing questionnaires, and interviews.

These data have been analyzed to determine the initial conditions of the process of learning the English language that has been taking place in the Junior High School (SMA) in Banda Aceh.

\section{Define}

Activity at this stage is to establish and define the terms of development. Defining the activities carried out through the analysis of development needs, the terms of the development of products that fit the needs of users as well as research and development models that is suitable for developing products. Development needs analysis is done through literature studies or preliminary research.

In the early stages, researcher examined the curriculum at this time. Competencies in the curriculum were to be achieved. Analysis curriculum is useful to establish the competence which the development model of based character. Based on the findings of the initial studies at senior high school in the city of Banda Aceh generally the teachers use education unit level curriculum (SBC) that prioritizes student's cognitive level.

Furthermore, the researcher conducted an analysis of the character of the individual students include academic ability, physical characteristics, the ability of group work, learning motivation, economic and social background. In connection with the development model of learning the English language -based characters, characteristics of learners, it needed to know to prepare products or instructional materials that suit with academic ability, for example: if the level of education of students is still low, the writing of teaching materials should use easy and simple language. If the 
students' reading ability is low, the teaching materials need to be coupled with attractive illustrations so that learners are motivated.

Based on the findings in the field, it was known that in general, students' academic ability of English was focused on cognitive and intellectual level regardless of the attitude factor (affective, so that the desired character is not achieved well. The physical characteristics of students tended to be good, when it was viewed in terms of dressing procedures. The students' ability in group work was still low, the students did not respect among their peers, and less concerned with their friends.

In terms of students' motivation, it was found that in general, students' motivation was low. Furthermore, in general, economic and social backgrounds of the students were already at an intermediate level.

\section{Design}

In the design phase, the researchers have already made the initial product (prototype) or product design. In the context of the development of teaching materials, this phase is done to create modules or textbooks in accordance with the contents of the analysis results framework curriculum and materials. In the context of the development of learning model, this stage are activities to prepare a conceptual framework and a model of learning devices (materials, media, evaluation tools) and simulate the use of the model and the learning device in a small scope.

Before the draft (design) product is continued to the next stage, the design of the product (teaching materials) needs to be validated. Validation of the design of the products is made by colleagues as professors or teachers of English subjects or areas of expertise together. Based on the results of the validation peers, there is the possibility of product design that still needs to be improved in accordance with suggestions of validate.

\section{Develop}

This activity is evaluated by experts based on their field. The suggestions given are used to improve the material and design of the learning that has been compiled. Developmental testing is an experimental activity in 
the product design targets. The trial results are used to improve the product. Once the repaired product is then tested back to obtain effective results.

In the context of development, the development stage is done by examining the content and the legibility of the modules or textbooks to the experts that involved during the design validation. The test results are then used for revision so that the module or the textbook can be used by the users. To determine the effectiveness of the modules or textbooks in improving learning outcomes, activities are continued to provide practice questions that the material taken from the module or textbook developed.

\section{Disseminate}

At the stage of validation testing, the products that have been revised at later stages of development will be implemented in the real targets. The measurement is conducted to determine the effectiveness of the products developed. The last activity of the development phase is to perform packaging (packaging), diffusion and adoption. This phase is carried out so that the product can be used by others. Packaging learning model can be done by printing the manual application of learning models. Once a book is printed, the book will be distributed in order to be absorbed or understood by users in their class.

In the context of the development of teaching materials, dissemination phase is done by means of dissemination of teaching materials through the distribution of a limited number of teachers and learners. This distribution is intended to obtain a response, feedback on teaching materials that have been developed. If the target user has good teaching materials, the new printing is done in large quantities and marketing of teaching materials that are used by a wider target.

Products/ draft of this research is a model of character-based learning English to improve English learning achievement of high school students in Banda Aceh.

The products of this learning method researchers have settle the whole matter to the activity -based model of learning English characters by applying active learning, in the form of material written and spoken English are very interactive. 
Based on the data findings, many teachers do not understand the activity -based model of learning English characters. In fact, they have applied the indicators of learning English character but they do not know that the indicators belong to learning English character. Many indicators of characters but this research is only focused on motivation, discipline, courtesy, cooperation, mutual love, mutual help, and responsibility.

Discipline of the students in the learning process is timely, complete the tasks given in accordance with the schedule set, and comply with regulations.

In motivation, the students are asked to study hard every time. They are asked to complete their work or home work. Besides, they are supported to dare to tell their opinions in discussion.

Furthermore, in courtesy, students are educated good manners to the teachers, the parents, other students, and friends. They are taught how to convey something in a polite way. For example when we ask, "What is your name?". This sentence is true and commonly used, but there is more polite e.g.: "Excuse me, would you like to tell me your name?" And so on. They are not only taught actions in good speech, but also behave well.

In terms of cooperation, the student learner to get accustomed to cooperate in completing the tasks assigned to him so that the tasks to be completed feels light. This cooperation is not only developed in the classroom but in other places, for example in the home and others.

In the character-based education is no less important is to love each other abdominal. In this case, the students love each other in the learning process. Love each other always mean that students help each other if there is a problem faced. For example, if a student is no pen, the pen more students who have to be able to lend. More detailed example is when a student is unable to complete the task; the students were able to be able to provide assistance. There by creating mutual love between them.

Furthermore, in terms of responsibility, the students are taught to be able to be responsible for the tasks assigned to them. They do not have the responsibility of the tasks only but also they must have a responsibility of action. With this responsibility, the students understand the rights and obligations. 


\section{Conclusion.}

As an international language, English is used in communication in the fields of science, technology, trade, politics, and the areas in which many nations have an interest. But in fact in Indonesia, English is still a foreign language taught in schools from elementary schools to high schools and even up to the level of Higher Education. In order to improve students' skills in English, then one alternative that is applied is to develop character-based English language learning. Character-based English language learning is expected to improve students' skills in English, as well as be able to indicate the identity of a civilized nation is sublime with the use of English well.

\section{Bibliography}

Ali, I.A. (2000). Pendidikan Karakter. Jakarta: Rajawali.

Bakar, A., \& Anwar, A. (2015). Learning Materials in Character Education. Jurnal Ilmiah Peuradeun, 3(3), 405-416.

Borg, R.W \& Gall, M.D. (1989). Education Research: An Introduction. Routledge: New York.

Mackey. (1997). Language Teaching Analysis. London: Longman.

Megawani, R. (2007). Pendidikan Karakter Solusi yang Tepat untuk Membangun Bangsa. Cetakan Kedua (Revisi). Bogor: Indonesia Heritage Foundation.

Rajab, Tarmizi. (2015). An Applied Model of Teaching Materials to Improve Students' Speaking Skill. Jurnal Ilmiah Peuradeun, 3 (1), p. 103-118, DOI: 10.13140/RG.2.1.1050.1848

Saifullah. (2015). The Internalization of Democratic Values into Education and Their Relevance to Islamic Education Development (Synthetic, Analytic, and Eclectic Implementation of John Dewey's Thoughts). Advanced Science Letters, Journal of Computational and Theoretical Nanoscience, 21 (7), pp. 2301-2304, DOI: 10.1166/asl.2015.6257

Salami, S. (2015). Implementing Neuro Linguistic Programming (NLP) in Changing Students' Behavior: Research Done at Islamic Universities in Aceh. Jurnal Ilmiah Peuradeun, 3(2), 235-256.

Subana. (2000). Statistik Pendidikan. Bandung: Pustaka Setia. 
Sulaiman, S. (2015). Classroom Management and the Implications to Quality of Learning. Jurnal Ilmiah Peuradeun, 3(3), 431-440.

Sulaiman. (2015). Classroom Management and the Implications to Quality of Learning (A Study About Classroom Climate at Madrasah Aliyah in Aceh, Indonesia). Jurnal Ilmiah Peuradeun, 3 (3), p. 431-440, DOI: 10.13140/RG.2.1.1271.3689

Usman, Muhammad. (2015). Teaching Model of Learning English Writing at University. Jurnal Ilmiah Peuradeun, 3 (3), p. 441-450. DOI: 10.13140/rg.2.1.3368.5200.

Wells. (1987). Perspectives in Critical Thinking: Essays by Teachers in Theory and Practice. New York: Peter Lang.

Yusoff, M. Z. M., \& Hamzah, A. (2015). Direction of Moral Education Teacher To Enrich Character Education. Jurnal Ilmiah Peuradeun, 3(1), 119-132.

ZA, T. (2014). Islamic Studies dalam Pendekatan Multidisipliner (Suatu Kajian Gradual Menuju Paradigma Global). Jurnal Ilmiah Peuradeun, 2(2), 211-234. 